\title{
Seasonal variation of size-fractionated phytoplankton in the Pearl River estuary
}

\author{
LI Li, LU SongHui*, JIANG Tao \& LI Xia \\ Research Center for Harmful Algae and Marine Biology, Key Laboratory of Eutrophication and Red Tide Prevention of Guangdong Higher \\ Education Institutes, Jinan University, Guangzhou 510632, China
}

Received May 13, 2012; accepted December 29, 2012

\begin{abstract}
To investigate the dynamics of phytoplankton size structure in the Pearl River estuary, concentrations of size-fractionated chlorophyll $a$ (Chl $a$ ) were determined during four cruises carried out in 2008 and 2010. The distribution of Chl $a$ in this geographical location showed a high degree of temporal variation. Chl $a$ concentrations were highest in autumn, approximately three times higher than those in summer and winter. Microphytoplankton was the dominant contributor, accounting for $66.9 \%$ of the Chl $a$ concentration in autumn 2008. In summer and spring 2008, nano-sized cells dominated the phytoplankton population throughout the study region. During the winter cruise, two different areas of water were found, characterized by (1) low salinity and high nutrient content and (2) high salinity and low nutrient content; nano- and picophytoplankton co-dominated the first area, while microphytoplankton dominated the second. It is arguable that grazing could have played a role in determining phytoplankton community size structure in winter. Nutrient concentrations were assumed not to limit phytoplankton growth during the investigation period. Size-differential capacity in competing for the resources available under different hydrodynamic conditions seemed to be the major factor in determining seasonal variation in the structure of the phytoplankton communities. High N:P ratios in the Pearl River estuary had major implications for nutrient pollution control. Our results indicated that studies of phytoplankton size structure provide greater insight into phytoplankton dynamics and are necessary to better manage water quality in the Pearl River estuary.
\end{abstract}

phytoplankton, dominant species, size-fractionated chlorophyll $a$, Pearl River estuary

Citation: $\quad$ Li L, Lu S H, Jiang T, et al. Seasonal variation of size-fractionated phytoplankton in the Pearl River estuary. Chin Sci Bull, 2013, 58: 2303-2314, doi: 10.1007/s11434-013-5823-1

Phytoplankton are a critical component of coastal and estuarine ecosystem food webs and phytoplankton community dynamics remain the most important issue in marine ecology $[1,2]$. Studies of the biological community from a sizebased perspective can lead to a better understanding of phytoplankton dynamics [3]. Furthermore, the size structure of marine phytoplankton assemblages reflects responses to environmental conditions [4-6]. Under oligotrophic or light-limiting conditions, small cells have a higher capacity for nutrient and light acquisition [7-9], whereas under favorable conditions for growth, namely high irradiance and nutrient concentrations, large-sized cells have a higher pho-

*Corresponding author (email: lusonghui1963@163.com) tosynthetic efficiency and a higher growth rate [3,6,10-12].

The Pearl River estuary is located in southern China. The Pearl River itself is the second largest river in China and the 13th largest river in the world in terms of discharge volume. The yearly average river discharge is $10524 \mathrm{~m}^{3} \mathrm{~s}^{-1}$, with $20 \%$ occurring in the dry season (October-March) and $80 \%$ occurring in the wet season (April-September) [13]. The river water empties via eight major channels into the South China Sea. Four of these enter the Lingdingyang estuary, a main subestuary of the Pearl River estuary, accounting for about $50 \%-55 \%$ of the Pearl River water flow; the remaining $45 \%-50 \%$ discharges directly into the South China Sea [14]. With several economic and industrial centers around the Lingdingyang estuary, such as Hong Kong, Macau, 
Shenzhen and Guangzhou, the delta region of the Pearl River is one of the most densely populated areas in China [15]. Over the past few decades, excessive wastes have been released into the estuary due to massive economic growth and urban development in the region [15-17]. The increased wastes provide nutrients that promote primary productivity in the receiving coastal waters and cause algal blooms. Eventually they result in eutrophication if the algae are not grazed by zooplankton [18], and such eutrophication has been a major issue in terms of the Pearl River estuary. To obtain an insight into the ecological effects of nutrient enrichment, one approach is to fractionate phytoplankton assemblages into different size classes, since cell size influences the response of phytoplankton communities to perturbation in the environment $[19,20]$. There have been several studies on phytoplankton biomass and size distribution of phytoplankton in the Pearl River estuary [21-24]. In our study, we investigated the dynamics of phytoplankton biomass in terms of chlorophyll $a(\mathrm{Chl} a$ ) content to reveal the spatial and temporal distribution patterns of total and sizefractionated phytoplankton biomass over an annual cycle.

\section{Materials and methods}

\subsection{Sampling stations}

The present study was based on four research cruises during the following time periods: April 2008, July 2008, October 2008 and January 2010. The sampling sites were located in the coastal water of Zhuhai $\left(22.1^{\circ} \mathrm{N}-22.3^{\circ} \mathrm{N}, 113.5^{\circ} \mathrm{E}-\right.$ $114^{\circ} \mathrm{E}$ ). A total of two transects were employed, with one transect (transect Z1-Z4) in the inner part of the estuary and the other (transect Z5-Z8) in the outer part of the estuary (Figure 1).

\subsection{Environmental factors}

Surface seawater was sampled to determine various environmental factors. A YSI 6600 multi-parameter water quality monitor (Yellow Springs Instrument Co., USA) was used to measure salinity and temperature. Surface water samples for the determination of inorganic nutrients (nitrite, nitrate, ammonium, phosphate and silicate) were filtered through $0.7 \mu \mathrm{m}$ Whatman $\mathrm{GF} / \mathrm{F}$ filters and stored at $-20^{\circ} \mathrm{C}$ until analyses were performed. The determination was performed using a SKALAR Continuous Flow Analyzer, using spectrometric methods described previously [25].

\subsection{Size-fractionated Chl $a$}

The phytoplankton was divided into three classes: micro$(>20 \mu \mathrm{m})$, nano- $(2-20 \mu \mathrm{m})$, and picophytoplankton $(<2 \mu \mathrm{m})$, and size fractions of $\mathrm{Chl} a$ were derived from sequential filtrations. Water samples taken from the surface water were first filtered through $20 \mu \mathrm{m}$ Nitex via gravity. Filtrates were

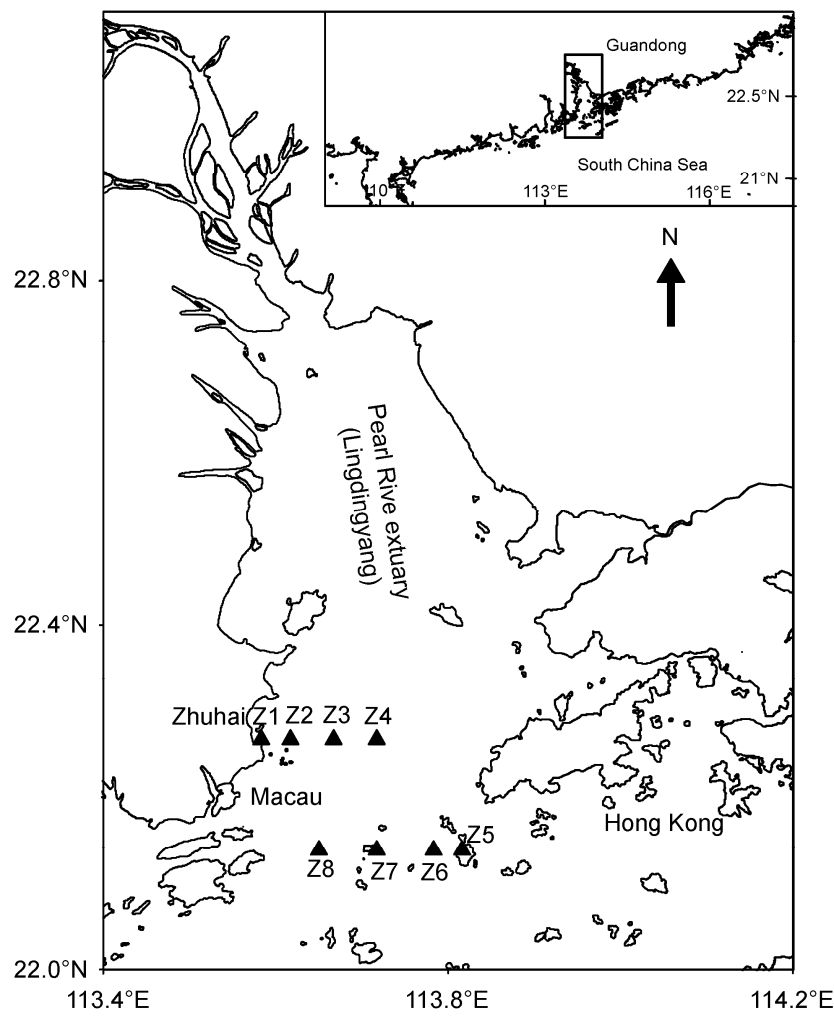

Figure 1 Sampling stations in the Pearl River estuary.

then sequentially filtered through $2 \mu \mathrm{m}$ Millipore Polycarbonate Nuclepore and $0.7 \mu \mathrm{m}$ Whatman GF/F filters under low vacuum pressure $(<100 \mathrm{mmHg})$. Chlorophyll retained by the $20-\mu \mathrm{m}$ filters was considered microphytoplankton biomass, and that retained by the 2 and $0.7 \mu \mathrm{m}$ filters constituted the nano- and picophytoplankton fractions, respectively. To determine the total $\mathrm{Chl} a$ concentration, $500 \mathrm{~mL}$ of water was directly filtered through a GF/F filter. After filtration, pigments were extracted in $10 \mathrm{~mL}$ of $90 \%$ acetone for $16-24 \mathrm{~h}$ in the dark at $4^{\circ} \mathrm{C}$. The fluorescence was then measured using a Turner Designs Fluorometer (BWT2X7200) [26] both before and after acidification with $10 \% \mathrm{HCl}$.

\subsection{Microscopic analysis of phytoplankton composition}

Subsamples of $1000 \mathrm{~mL}$ of seawater were distributed in Pyrex bottles and fixed immediately with Lugol's Solution, yielding a final concentration of $4 \%$. For microscopic observation, $10 \mathrm{~mL}$ of each fixed sample was settled in a sedimentation chamber for at least $24 \mathrm{~h}$. The bottom area of the whole chamber was examined under an inverted microscope (Nikon E200) to identify species and to enumerate the abundance of phytoplankton, as previously performed [27].

\subsection{Statistical analysis}

Pearson correlation analysis was used to determine relationships between the chlorophyll content of each phyto- 
plankton size class and the various physical and biological variables reported within each cruise and across all cruises. Analysis was performed using the SPSS 13.0 statistical package for Windows.

\section{Results}

\subsection{Environmental factors}

Temperature, in the range $17.06-27.56^{\circ} \mathrm{C}$, varied seasonally
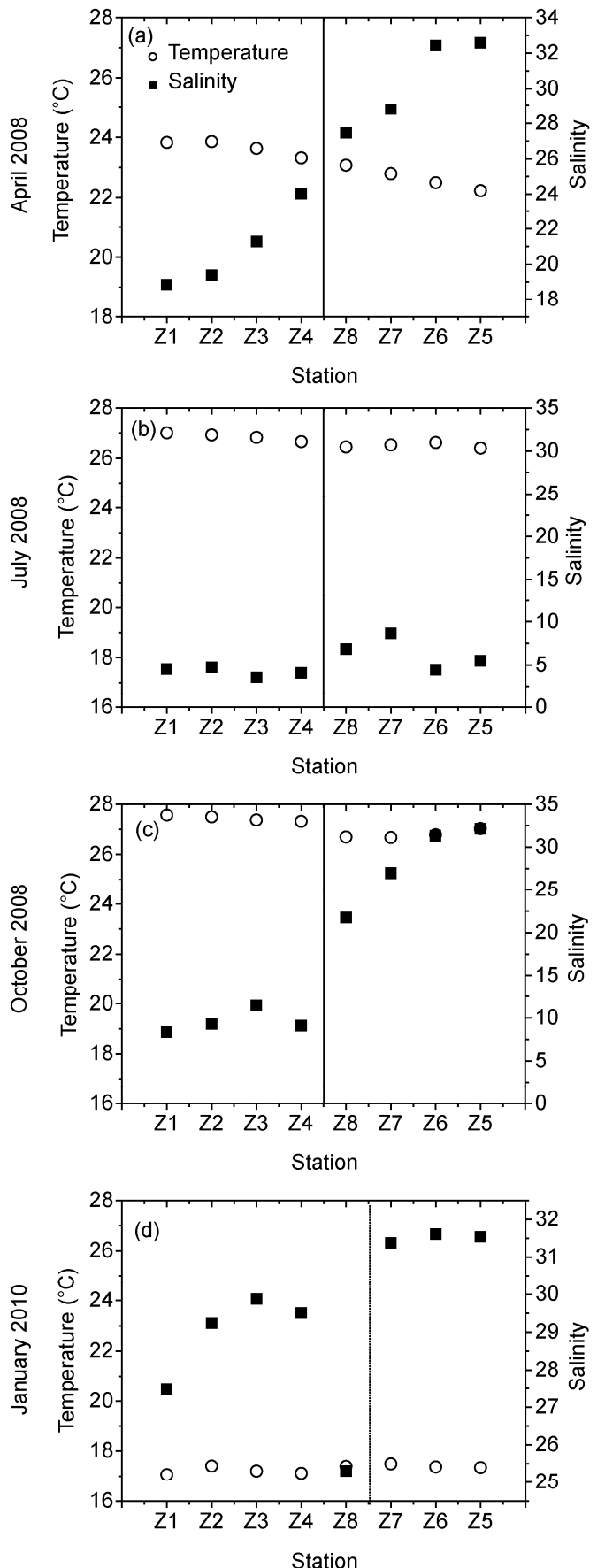

in the Pearl River estuary, with the lowest value occurring in winter (Figure 2(d)). In summer and autumn, temperatures were higher, averaging 26.68 and $27.11^{\circ} \mathrm{C}$, respectively. Surface temperature varied little across stations (Figure 2(a)-(d)). In the case of salinity, values were consistently lower in the inner part of the study area than those in the outer part (Figure 2(a)-(d)), especially during the autumn cruise. The average salinity of the inner part of the study area was 9.55. This was almost three times lower than that found in the outer part of the study area, reflecting the
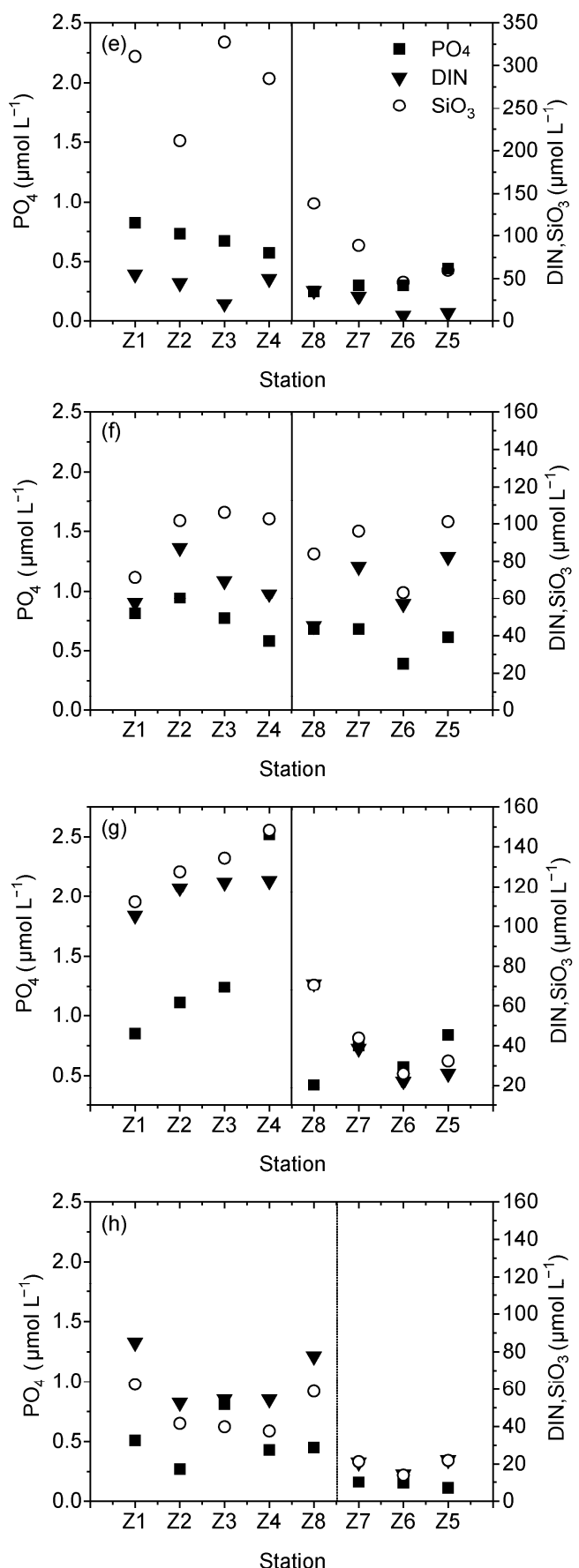

Figure 2 Spatial distributions of (a)-(d) temperature and salinity, and (e)-(h) nutrient concentrations during the four cruises. 
strong interaction between fresh water and seawater.

Dissolved inorganic nitrogen (DIN) concentrations ranged from 6.35 to $123.08 \mu \mathrm{mol} \mathrm{L} \mathrm{L}^{-1}$ during the investigation period. The seasonal variability revealed that DIN concentrations in summer and autumn were higher than those in spring and winter (Figure 2(e) and (f)). Phosphate $\left(\mathrm{PO}_{4}\right)$ concentrations varied between $0.11-2.52 \mu \mathrm{mol} \mathrm{L} \mathrm{L}^{-1}$, with $87.5 \%$ of the values being lower than $1.0 \mu \mathrm{mol} \mathrm{L}{ }^{-1}$ (Figure 2(e) and (f)). Higher $\mathrm{PO}_{4}$ concentrations $\left(>1 \mu \mathrm{mol} \mathrm{L}{ }^{-1}\right)$ were found in autumn in the inner part of study area (Figure $2(\mathrm{~g})$ ). Silicate $\left(\mathrm{SiO}_{3}\right)$ concentrations varied significantly from 14.11-327.37 $\mu \mathrm{mol} \mathrm{L}{ }^{-1}$. Unlike phosphate concentrations, higher silicate concentrations were found in spring (Figure 2(e)). The lowest $\mathrm{PO}_{4}$ and $\mathrm{SiO}_{3}$ concentrations were observed during the winter cruise (Figure 2(h)). In winter, two different areas were identified: (1) An area of higher nutrient content and lower salinity $(<30)(Z 1-Z 4, Z 8)$; and (2) an area of lower nutrient content and higher salinity $(>30)$ (Z5-Z7) (Figure 2(d) and (h)).

\subsection{Total Chl $a$ and size-fractionated Chl $a$ concentra- tions}

During the spring cruise, total $\mathrm{Chl} a$ concentration ranged from 4.40 to $15.60 \mu \mathrm{g} \mathrm{L}^{-1}$. The highest Chl $a$ concentration of $15.60 \mu \mathrm{g} \mathrm{L}^{-1}$ was found at station Z4 (Figure 3(a)). The concentration of microphytoplankton $\mathrm{Chl} a$ ranged from 1.50 to $8.05 \mu \mathrm{g} \mathrm{L}^{-1}$, and the highest microphytoplankton Chl $a$ concentration was observed at station $\mathrm{Z} 4$. The proportion of the micro-sized fraction concentration to the total Chl $a$ concentration varied between $16.4 \%$ and $51.6 \%$. The concentration of nanophytoplankton $\mathrm{Chl} a$ concentration was in the range $2.15-8.75 \mu \mathrm{g} \mathrm{L}^{-1}$, accounting for more than $50 \%$ at most stations (Figure 3(e)). Picophytoplankton Chl $a$ concentrations in the spring cruise were generally less than $1.0 \mu \mathrm{g} \mathrm{L}^{-1}$, with the exception being at $\mathrm{Z6}$. The percentages of the pico-sized fraction were less than 20\% (Figure 3(e)).

In summer, the total $\mathrm{Chl} a$ concentration ranged from 0.31 to $4.52 \mu \mathrm{g} \mathrm{L}^{-1}$, with $\mathrm{Chl} a$ distribution gradually increasing seaward (Figure 3(b)). The average Chl $a$ concentration in the inner part of the study area $\left(0.74 \mu \mathrm{g} \mathrm{L} \mathrm{L}^{-1}\right)$ was almost four times lower than that in the outer part $(3.04 \mu \mathrm{g}$ $\left.\mathrm{L}^{-1}\right)$. Size-fractionated Chl $a$ concentrations showed similar trends to the total Chl $a$ concentration, with high levels in the outer part of the river mouth. Nanophytoplankton was predominant in summer, making up over $80 \%$ of the phytoplankton biomass in half of the sampling stations (Figure 3(f)).

In autumn, Chl $a$ concentration was significantly higher than that in the other three seasons. The range of total Chl $a$ concentration was 3.03-18.01 $\mu \mathrm{g} \mathrm{L}^{-1}$. Unlike that of the summer and spring cruises, the Chl $a$ level near the shore was relatively higher than that more offshore, with the highest value at station Z8 (Figure 3(c)). Similar trends were exhibited by the micro- and nano-Chl $a$ concentrations.
Pico-Chl $a$ concentrations were in the range 0.30-2.01 $\mu \mathrm{g} \mathrm{L}{ }^{-1}$. High picophytoplankton biomass was only observed at station $\mathrm{Z} 2$ and in the rest of the study area, the Chl $a$ concentration of picophytoplankton was generally in the range $0.30-0.57 \mu \mathrm{g} \mathrm{L}^{-1}$. The phytoplankton community was dominated by microphytoplankton during the autumn cruise. The proportion of micro-sized fractions to total Chl $a$ content ranged between $46.7 \%$ and $81.7 \%$, with a mean of $66.9 \%$. The nanophytoplankton was another important group, which was observed to occupy $15.3 \%-56.0 \%$ of the total Chl $a$ content (Figure 3(g)).

In winter, the Chl $a$ concentration varied from 2.27 to $3.87 \mu \mathrm{g} \mathrm{L}^{-1}$. Unlike the other three seasons, there was not much spatial variation in the whole region (Figure $3(\mathrm{~d})$ ). Relatively high Chl $a$ concentrations were found at station $\mathrm{Z6}, \mathrm{Z7}$ and Z2. Micro-Chl $a$ concentration was in the range $0.39-2.22 \mu \mathrm{g} \mathrm{L}^{-1}$ and increased seaward. Nano-Chl $a$ concentration had the opposite distribution pattern, with higher levels in the inner part of estuary. It can be seen that nano$(35.9 \%-48.6 \%)$ and picophytoplankton (22.9\%-44.6\%) collectively dominated in stations $\mathrm{Z} 1-\mathrm{Z} 4$ and Z8 (Figure 3(h)), whereas microphytoplankton was significant at stations Z5-Z7 (Figure 3(h)). It should be noted that picophytoplankton increased its importance in January 2010, its contributions during that cruise being much higher than those of the other three cruises.

\subsection{Phytoplankton biomass and dominant phyto- plankton species}

The phytoplankton in the Pearl River estuary exhibited a high species biodiversity. There were 178 phytoplankton taxa identified: $65 \%$ belonged to the Bacillariophyta, $16.4 \%$ to the Pyrrhophyta, $9.0 \%$ to the Cyanophyta, and $9.7 \%$ to other species. Phytoplankton biomass ranged from $0.27 \times 10^{5}$ to $1.12 \times 10^{8}$ cells $\mathrm{L}^{-1}$, with a mean of $0.91 \times 10^{7}$ cells $\mathrm{L}^{-1}$. The maximum phytoplankton abundance occurred during autumn at station Z8, whereas the minimum occurred during summer at station $\mathrm{Z} 1$. The abundance of phytoplankton during the autumn cruise was two or three orders of magnitude higher than those of the other three seasons (Figure 4(a)-(d)).

Diatoms dominated the phytoplankton community during the winter, spring and autumn cruises (Figure 4(a), (c), and (d)), while blue-green algae dominated during the summer cruises (Figure 4(b)). The dominant population changed with an obvious seasonal succession. During the spring and autumn cruises, Skeletonema costatum dominated almost all of the sampling stations, accounting for 54.8\%-97.0\% (averaging $72.2 \%$ ) of the total abundance in spring (Figure 4(e)) and $54.5 \%-99.6 \%$ (averaging $87.6 \%$ ) in autumn (Figure $4(\mathrm{~g}))$. However, abundance of $S$. costatum in spring was one or more orders of magnitude lower than in autumn (Figure 4(a) and (c)). In winter, Chaetoceros curvisetus was dominant in all stations (Figure 4(h)). Other major species 

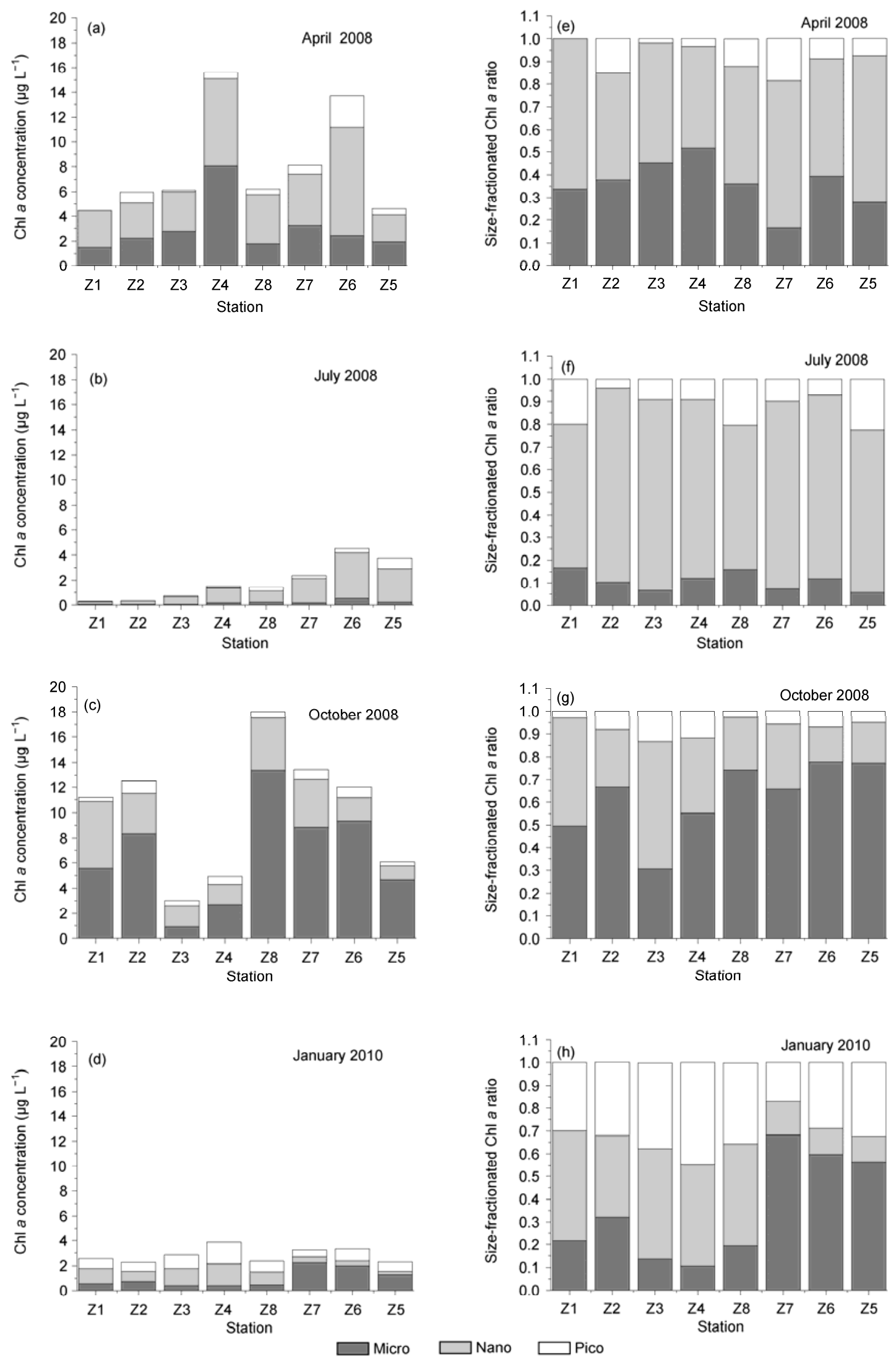

Figure 3 Spatial distribution of (a)-(d) total Chl $a$ and (e)-(h) percentages of the micro-, nano- and pico-size fractionated Chl $a$ concentration to total Chl $a$ concentration. 
included Thalassiosira spp., Chaetoceros debilis and Chaetoceros socialis (Figure 4(h)). Blue-green algae dominated the community during the summer cruise in most stations (Z3-Z8), and the dominant species varied with different stations (Figure 4(b) and (f)). Pseudoanabaena sp. was an important species in stations Z3-Z5, accounting for more than $30 \%$ of the total abundance. Comparably, Merismopedia tenuissima became the dominant species at stations Z6-Z8, representing at least $22.2 \%$ of the total abundance (Figure 4(f)). Diatoms were the most abundant taxa only in stations Z1 and Z2, with Melosira sp. being dominant in station Z1 and Skeletonema tropicum being dominant in station Z2.

\subsection{Relationships between environmental variables and Chl $a$ distribution}

Table 1 shows the results of Pearson relation analyses of relationships between the Chl $a$ concentrations of various phytoplankton size classes and various environmental properties. In spring and autumn, environmental variables were not correlated with any size class of Chl $a$ (Table 1). Microand nano-Chl $a$ classes were negatively correlated with phosphorus concentrations in summer. In winter, a significantly negative correlation between the micro-Chl $a$ size class and nutrient concentrations (DIN, $\mathrm{PO}_{4}, \mathrm{SiO}_{3}$ ) was observed, whereas nano-Chl $a$ was positively correlated with DIN and $\mathrm{PO}_{4}$ concentrations. Nano-Chl $a$ was negatively correlated with temperature in winter. We also observed negative correlations of pico-Chl $a$ with temperature and silicate concentrations when values from all seasons and stations were pooled.

\section{Discussion}

Seasonal variation in the structure of phytoplankton communities is common in estuaries such as Chesapeake Bay [28], and contributions of size-fractionated $\mathrm{Chl} a$ in the Pearl River estuary showed a large seasonal fluctuation (Figure 3(e)-(h)). In spring and summer, nanophytoplankton formed the bulk of the phytoplankton biomass, which is consistent with results previously reported $[23,24]$. In autumn, the microphytoplankton was dominant in our study. However, picophytoplankton $(\leqslant 3 \mu \mathrm{m})$ was most dominant in autumn 2005 [24]. We have no clear explanation for these differing observations. However, about ten days before our investigation in autumn 2008, tropical storm Higos arrived at Guangdong. As reported in previous studies, typhoons or tropical cyclones cause temporal influences on the phytoplankton. For example, remote sensing studies revealed that Typhoon Kai-Tak in 2000 triggered a thirtyfold increase in surface Chl $a$ concentrations over the South China Sea [29]. Blooms of phytoplankton were also observed after cyclonic disturbances in subtropical coastal waters, and species greater than $5 \mu \mathrm{m}$ were responsible for the rapid increase of phytoplankton following a cyclone [30]. The average $\mathrm{NO}_{3}$, $\mathrm{NO}_{2}, \mathrm{PO}_{4}$ concentrations were $43.65 \pm 35,8.43 \pm 8.21$ and $0.78 \pm 0.55 \mu \mathrm{mol} \mathrm{L}^{-1}$, respectively, in September 2005 [24] and were $66.75 \pm 38.47,8.71 \pm 4.91$ and $1.04 \pm 0.65 \mu \mathrm{mol} \mathrm{L}^{-1}$ in October 2008, indicating the higher nutrient levels after tropical storms. The fact that the phytoplankton was dominated by microphytoplankton in October 2008 might have been due to wind event-induced elevation of nutrient levels, which in turn reduced the levels of competition for nutrients between larger and smaller phytoplankton species. Thus, the photosynthetic rate of the former group might have been enhanced [30-32].

Among the factors affecting phytoplankton size structure in different marine ecosystems, temperature, light and nutrient supply have been suggested to be the major ones $[9,11,33]$. According to the criteria of Dortch and Whitledge [34], Si limitation occurs if $\mathrm{Si}: \mathrm{N}<1$ and $\mathrm{Si}<2 \mu \mathrm{mol} \mathrm{L}^{-1} ; \mathrm{P}$ limitation occurs if $\mathrm{N}: \mathrm{P}>30$ and $\mathrm{P}<0.2 \mu \mathrm{mol} / \mathrm{L}$; and $\mathrm{N}$ limitation occurs when $\mathrm{N}: \mathrm{P}<10$ and $\mathrm{DIN}<1 \mu \mathrm{mol} \mathrm{L}^{-1}$. In our study, $\mathrm{N}: \mathrm{P}$ was always higher than 10 throughout the sampling period and the minimum value of $\mathrm{N}$ concentration was $6.35 \mu \mathrm{mol} \mathrm{L}{ }^{-1}$. Thus, phytoplankton growth was not limited by $\mathrm{N}$ content. Furthermore, $\mathrm{Si}: \mathrm{N}>1$ and the minimum observed value of $\mathrm{Si}$ concentration was $16.02 \mu \mathrm{mol} \mathrm{L}^{-1}$ during the spring, summer, and autumn cruises. In winter, although $\mathrm{Si}$ : $\mathrm{N}$ was less than 1 in most of the sampling stations, $\mathrm{Si}$ concentration was always higher than $10 \mu \mathrm{mol} \mathrm{L}{ }^{-1}$. Therefore, $\mathrm{Si}$ was considered not to be a limiting factor in the area. As a result of higher inputs of $\mathrm{N}$ from the Pearl River in summer, $\mathrm{P}$ potentially limits the amount of algal biomass during that season [35-37]. In the case of our study, although $\mathrm{N}: \mathrm{P}$ was always high and occasionally more than 200, P concentrations were almost always higher than 0.2 $\mu \mathrm{mol} \mathrm{L}{ }^{-1}$. Therefore, $\mathrm{P}$ was assumed not to be the limiting factor for phytoplankton growth during our study. Thus, nutrient content was assumed to be saturated in our study area.

Previous studies [38] conclude that microphytoplankton abundance increases and picophytoplankton decreases as latitude increases. In the present work, statistical analysis indicated a significantly inverse correlation between pico-Chl $a$ concentration and temperature $(P<0.01)$ when values from all seasons and stations are pooled (Table 1). However, it was also reported that surface temperature does not exert a direct control on picophytoplankton variability [39]. In the natural ocean environment, temperature and nutrient content are strongly covariant [33]. The inverse relationship observed between picophytoplankton and surface temperature can be explained from the correlation analyses. Consequently, when considering the effects of temperature on phytoplankton size structure, it is recommended that the concentration of nutrients be considered at the same time. 

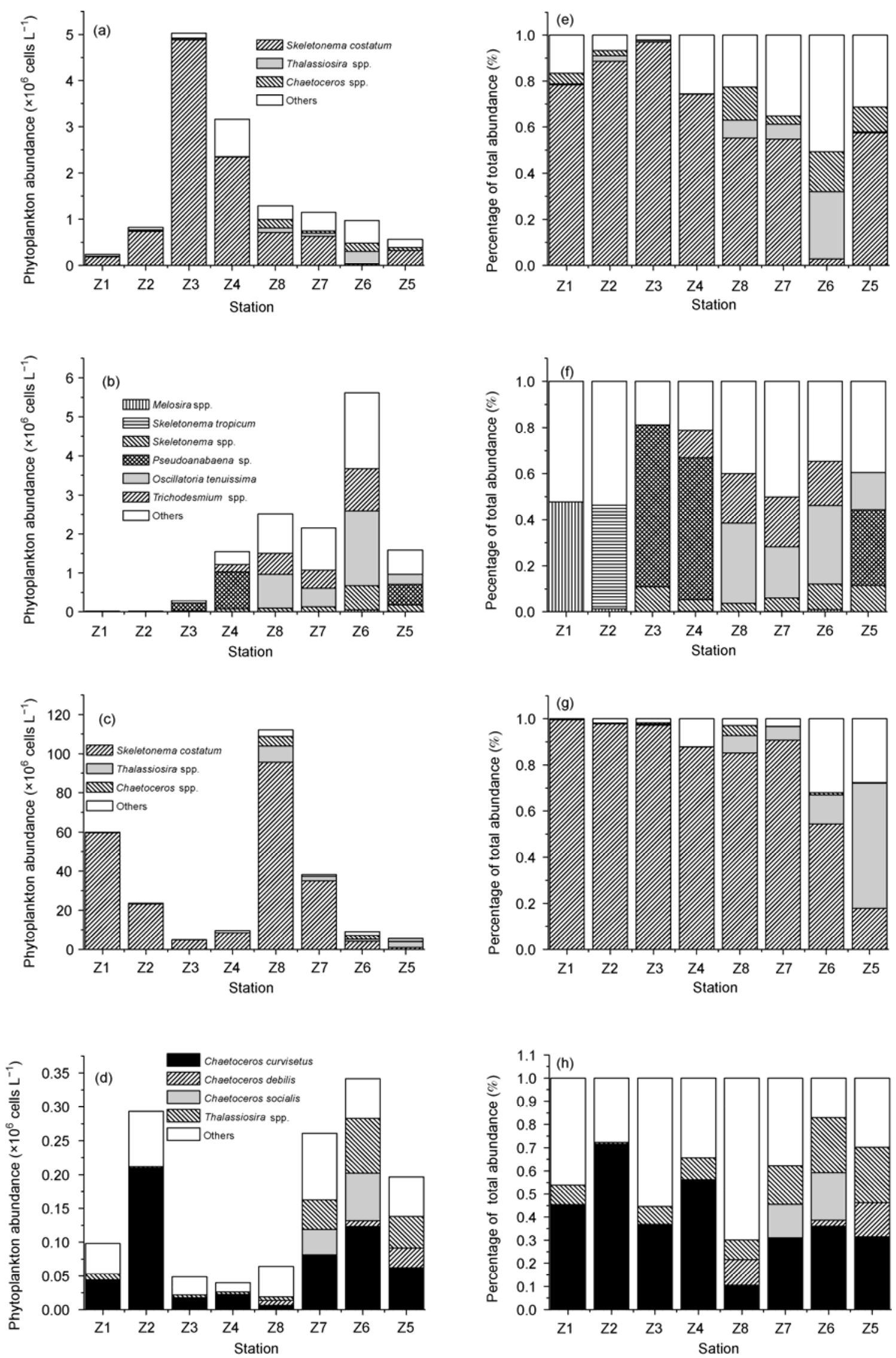

Figure 4 Spatial distribution of (a)-(d) major phytoplankton abundance and (e)-(h) percentage of total abundance. 
Table 1 Pearson correlation coefficients for each independent variable and significance between phytoplankton Chl $a$ versus temperature, salinity and nutrients ${ }^{\text {a) }}$

\begin{tabular}{|c|c|c|c|c|c|c|c|}
\hline Variable & Season & Number of measurements & Temperature & Salinity & DIN & $\mathrm{PO}_{4}$ & $\mathrm{SiO}_{3}$ \\
\hline \multirow[t]{5}{*}{ Micro-Chl $a$} & Spring & 8 & $0.431^{\text {n.s. }}$ & $-0.401^{\text {n.s. }}$ & $0.298^{\text {n.s. }}$ & $0.410^{\text {n.s. }}$ & $0.606^{\text {n.s. }}$ \\
\hline & Summer & 8 & $-0.536^{\text {n.s. }}$ & $0.086^{\text {n.s. }}$ & $-0.376^{\text {n.s. }}$ & $-0.914 * *$ & $-0.592^{\text {n.s. }}$ \\
\hline & Autumn & 8 & $-0.637^{\text {n.s. }}$ & $0.413^{\text {n.s. }}$ & $-0.456^{\text {n.s. }}$ & $-0.669^{\text {n.s. }}$ & $-0.526^{\text {n.s. }}$ \\
\hline & Winter & 8 & $0.644^{\text {n.s. }}$ & $0.699^{\text {n.s. }}$ & $-0.844^{*}$ & $-0.758^{*}$ & $-0.799 *$ \\
\hline & Across cruise & 32 & $0.310^{\text {n.s. }}$ & $0.233^{\text {n.s. }}$ & $0.047^{\text {n.s. }}$ & $0.044^{\text {n.s. }}$ & $0.059^{\text {n.s. }}$ \\
\hline \multirow[t]{5}{*}{ Nano-Chl $a$} & Spring & 8 & $-0.241^{\mathrm{n} . \mathrm{s} .}$ & $0.148^{\text {n.s. }}$ & $-0.186^{\text {n.s. }}$ & $0.062^{\text {n.s. }}$ & $-0.171^{\text {n.s. }}$ \\
\hline & Summer & 8 & $-0.639^{\text {n.s. }}$ & $0.182^{\text {n.s. }}$ & $0.015^{\text {n.s. }}$ & $-0.866^{* *}$ & $-0.325^{\text {n.s. }}$ \\
\hline & Autumn & 8 & $0.052^{\text {n.s. }}$ & $-0.297^{\text {n.s. }}$ & $0.160^{\text {n.s. }}$ & $-0.401^{\text {n.s. }}$ & $0.076^{\text {n.s. }}$ \\
\hline & Winter & 8 & $-0.747^{*}$ & $-0.531^{\text {n.s. }}$ & $0.726 *$ & $0.807^{*}$ & $0.641^{\text {n.s. }}$ \\
\hline & Across cruise & 32 & $0.211^{\text {n.s. }}$ & $0.122^{\text {n.s. }}$ & $-0.045^{\text {n.s. }}$ & $-0.088^{\text {n.s. }}$ & $0.344^{\text {n.s. }}$ \\
\hline \multirow[t]{5}{*}{ Pico-Chl $a$} & Spring & 8 & $-0.281^{\mathrm{n} . \mathrm{s} .}$ & $0.330^{\text {n.s. }}$ & $-0.527^{\text {n.s. }}$ & $-0.536^{\text {n.s. }}$ & $-0.637^{\text {n.s. }}$ \\
\hline & Summer & 8 & $-0.776^{*}$ & $0.254^{\text {n.s. }}$ & $0.151^{\text {n.s. }}$ & $-0.497^{\text {n.s. }}$ & $0.025^{\text {n.s. }}$ \\
\hline & Autumn & 8 & $-0.131^{\mathrm{n} . \mathrm{s} .}$ & $0.021^{\text {n.s. }}$ & $-0.034^{\text {n.s. }}$ & $0.001^{\text {n.s. }}$ & $-0.034^{\text {n.s. }}$ \\
\hline & Winter & 8 & $-0.597^{\text {n.s. }}$ & $-0.032^{\text {n.s. }}$ & $0.152^{\text {n.s. }}$ & $0.369^{\text {n.s. }}$ & $0.034^{\text {n.s. }}$ \\
\hline & Across cruise & 32 & $-0.442 *$ & $0.512^{\text {n.s. }}$ & $-0.308^{\text {n.s. }}$ & $-0.219^{\text {n.s. }}$ & $-0.363^{*}$ \\
\hline
\end{tabular}

a) n.s., $p>0.05 ; *, p<0.05 ; * *, p<0.01$.

In addition to nutrient concentrations and temperature, some authors suggest that phytoplankton size structure might be controlled primarily by hydrodynamics in the ocean [40]. Thus, water column stability determines the size-differential residence time of phytoplankton cells within the euphotic layer $[9,40,41]$. In the case of the Pearl River estuary, during the wet season, the whole estuary is highly stratified and greatly influenced by freshwater discharge. Due to strong stratification, high temperatures, and nutrient input from freshwater runoff, it is assumed that the micro-sized fraction is predominant in the phytoplankton biomass. However, as a result of high river discharge, especially during the period of maximal river discharge in June and July, the Pearl River estuary has a water residence time of less than three days [37,42], and the time might not be enough for phytoplankton growth, especially for microphytoplankton [24]. During the dry season, the Pearl River discharge is small, the water residence time is prolonged, and the water column is vertically homogeneous. Vertical mixing could have a favorable effect, e.g. upward motion could increase the residence time of large cells in the upper layer [41]. On the other hand, strong vertical motion could lift phytoplankton from the eutrophic zone, which would be in favor of the smaller cells that have an advantage under weak light conditions [3]. As a result, seasonal variations in the size structure of phytoplankton in the Pearl River estuary were, to a great extent, under the control of the sizedependent competitive abilities in a dynamic environment associated with physical processes such as river discharge, stratification and water vertical mixing.

Phytoplankton biomass and associated productivity may be dominated by large phytoplankton size fractions in waters supplied with high-nutrient concentrations [43]. Thus, during the winter cruise, higher nutrient levels in $\mathrm{Z} 1-\mathrm{Z4}$ and Z8 led to the expectation that the larger cells would exhibit greater abundance. On the contrary, phytoplankton Chl $a$ was co-dominated by the nano- and pico-sized fractions, whereas in lower nutrient concentration conditions, microphytoplankton was dominant (Figures 2(h) and 3(h)). Light limitation of phytoplankton growth is suggested as an explanation for similarly observed phenomena [44]. This previous study revealed that growth of large cells in the York River estuary is dependent on nitrite, nitrate input, but only when light is unlimited. However, our study was based on data collected at the water surface. Thus, radiation was assumed to be saturated and non-limiting on phytoplankton growth. As previously discussed [32,45], zooplankton grazing also plays an important role in controlling the size distribution of phytoplankton communities. Large phytoplankton cells are more likely to be ingested by a mesozooplankton dominated by copepods [46-50]. Copepods are the most abundant mesozooplankton in winter in the Pearl River estuary [50,51], and salinity is one of the most important physical factors affecting zooplankton abundance and species richness in the Pearl River estuary [50-53]. In winter, mesozooplankton abundance and biomass are negatively related with salinity [51]. In $<30$ salinity areas, grazing pressure of zooplankton (especially copepods) is high [24,54]. Thus, in higher nutrient but lower salinity areas, the mesozooplankton might be abundant. Therefore, grazing pressure exerted on the microphytoplankton might be the reason that small-sized phytoplankton dominated in this area. This is the most likely reason why we observed that microphytoplankton Chl $a$ was positively and negatively correlated with salinity and nutrient concentrations, respectively (Table 1). 
In terms of the phytoplankton community, previous studies document that diatoms are always the main contributors in and near the Pearl River estuary [55,56]. Although the composition of dominant species varies in different years, S. costatum is always prominent in summer [62]. However, in the present study, fresh-water species of bluegreen algae were dominant, representing $55.3 \%$ of the total phytoplankton abundance during the summer cruises (Figure 4(b) and (f)). The relative availability of nutrients plays an important role in structuring phytoplankton communities [57]. Diatoms have an absolute requirement for silicon [58]. Only after the depletion of nutrients (mainly silicate), would other phytoplankton species be expected to take over [59]. In our case, limitation of silicate did not seem to occur since silicate concentrations (63.29-109.95 $\left.\mu \mathrm{mol} \mathrm{L}^{-1}\right)$ were high, with $\mathrm{Si}: \mathrm{N}>1$ and $\mathrm{Si}: \mathrm{P}>16$. As for $\mathrm{PO}_{4}$, it is suggested that a low concentration of phosphate limits the growth of diatoms in seawater [60], and that the growth of S. costatum in marine ecosystems can be limited when $\mathrm{P}$ concentration is less than $0.3 \mu \mathrm{mol} \mathrm{L}{ }^{-1}$ [61]. Within the range 0.39-0.94 $\mu \mathrm{mol} \mathrm{L} \mathrm{L}^{-1}$, our $\mathrm{PO}_{4}$ values were comparable to those observed previously in several studies on the Pearl River estuary $[23,62]$. Hence, $\mathrm{P}$ concentrations during the summer cruise could not explain the replacement of diatoms by blue-green algae. Several recent studies note that there is a general trend of an increase in relative Cyanobacterial abundance with increasing water temperature, and decreased flushing rate $[63,64]$. During June 2008, cities located in the upper reach of the Pearl River drainage basin, including Guangzhou, Dongguan and Foshan, had the highest rainfall in the all-time record. Taking Guangzhou as an example, the average rainfall was $878.1 \mathrm{~mm}$ in June 2008, about $40 \%$ of the annual total precipitation. The air average temperature was $26.7^{\circ} \mathrm{C}$. While in July, the precipitation decreased to $231 \mathrm{~mm}$, accompanied by an increasing air temperature to $28.5^{\circ} \mathrm{C}$ (http://www.gzstats.gov.cn). In other years, the differential precipitation between two consecutive months was not as great as we found in June and July 2008. As we know, rainfall is generally positively related to river flow, air temperature can reflect water temperature, and massive river effluents may bring large amounts of blue-green algae. When the flushing rate was markedly decreased in July 2008, accompanied by increasing temperature, the blue-green algae might have responded prior to the diatoms to the dramatic changes in the environment. Thus, dominance of the blue-green algae probably suggested their quicker response relative to diatoms to the markedly decreased flushing rate in July 2008 relative to June 2008.

The Pearl River estuary is the principal receiving water body of land-based pollutants destined for the South China Sea. In the past decades, the large amounts of waste water coming from industrial and domestic sources were only partly treated, but were discharged into the river or coastal waters directly. In the Pearl River delta, domestic sewage is more than $6.0 \times 10^{8} \mathrm{~m}^{3}$ per year (not including Hong Kong and Macau). Less than $30 \%$ is treated, and the remainder is discharged without any treatment $[15,65]$. Agricultural fertilizers and mariculture are also main sources of pollutants for the estuary [15]. DIN in the Pearl River estuary mainly comes from the four river channels in the main estuary [15]. However, relative to the $\mathrm{PO}_{4}$ from the vertical mixing of deep water to the surface, the $\mathrm{PO}_{4}$ load from the river does not enhance the $\mathrm{PO}_{4}$ concentration [36]. Results from an earlier study indicate that the amounts of DIN inputted from four river channels (Humen, Jiaomen, Hongqimen, Hengmen) are about 30 times more than those of phosphate [15]. Due to the anthropogenic loading of nutrients in the rivers disproportionally increasing $\mathrm{N}$ and $\mathrm{P}$, a $100 \mathrm{~N}: 1 \mathrm{P}$ ratio (about seven times higher than the normal Redfield ratio of $16 \mathrm{~N}$ : $1 \mathrm{P}$ that is optimal for phytoplankton growth) occurs [36]. In the present study, $N: P$ ratios generally exceeded $16: 1$, with $62.5 \%$ greater than $100: 1$. A high $\mathrm{N}: \mathrm{P}$ ratio has become a characteristic feature of coastal areas affected by freshwater discharge $[60,66]$. In the other large estuaries of China, such as the Yellow River estuary [67], and the Changjiang estuary [60], a higher $\mathrm{N}$ : $\mathrm{P}$ ratio is also observed. Alterations in nutrient ratios, such as $\mathrm{N}: \mathrm{Si}$ and $\mathrm{N}: \mathrm{P}$ as a result of excess $\mathrm{N}$ relative to $\mathrm{Si}$ and $\mathrm{P}$, can change phytoplankton biomass and species composition [68,69]. In the Black Sea, the increasing $\mathrm{N}$ and $\mathrm{P}$ relative to $\mathrm{Si}$ results in the dominance of phytoplankton such as coccolithophores and flagellates instead of diatoms [70]. In the Bohai Sea, the replacement of diatoms by dinoflagellates is the major characteristic of variations in the phytoplankton community in recent years, which probably result from increasing $\mathrm{N}: \mathrm{P}$ ratio and decreasing $\mathrm{Si}: \mathrm{N}$ ratio [71]. In such a case, the result may have significant implications for local nutrient pollution control. The removal of $\mathrm{N}$ through sewage treatment as a means of controlling nutrient effluent discharge into the coastal waters in the vicinity of the Pearl River estuary should be considered.

In spring, S. costatum was most abundant (Figure 4(a) and (e)), accounting for $72.2 \%$ of the total phytoplankton cell count. It is worth noting that $S$. costatum dominated the phytoplankton assemblage in autumn as well (Figure 4(c) and (f)), and accounted for $87.6 \%$ of the phytoplankton biomass. This result is supported by a study [24], and similar results are shown in 1999-2000 in the same estuary, where $S$. costatum was observed as the dominant species in both summer and winter [62]. Other results [72] reveal that this chain-forming diatom is capable of tolerating extreme physico-chemical conditions, offering an explanation as to why it is dominant in the phytoplankton assemblages of both the spring and autumn cruises. However, the nanosized fraction dominated the phytoplankton population in spring, whereas the micro-sized fraction was dominant in autumn. We might attribute this to the survival strategy of $S$. costatum adapting to changes of its environment. Phytoplankton changes its structure, composition and physiology 
as an adaptation to altered environments [73] and, in a study on several species of epilithic diatoms, size variation in a natural population within a diatom species is described and they are found to respond to environmental conditions very differently [74]. From the results of a monitoring and subsequent mesocosm study [75], cells of $S$. costatum, of both larger $(20-200 \mu \mathrm{m})$ and smaller fractions $(2-20 \mu \mathrm{m}$ and to a lesser extent $0.2-2 \mu \mathrm{m}$ ) are found to exist in the water column at the same time, and the photosynthetically active radiation quantum controlled the relative abundance of one size class over the other. Since our study was conducted at the water surface, light conditions might be ruled out as a controlling factor to determine the size class of $S$. costatum. On the other hand, the identification of phytoplankton $<5$ $\mu \mathrm{m}$ in size is difficult with an inverted microscope and, possibly, a large number of phytoplankton with cell size between 2 and $5 \mu \mathrm{m}$ existed in the water column from the spring cruise, suggesting that analyses of phytoplankton size structure are necessary to better understand phytoplankton dynamics.

Physical fractionation using differential filtration is the most widely used method to group phytoplankton into different size classes. Despite its simplicity and widely accepted use, precise control of the filtration technique is difficult, since the size separation is influenced by a variety of factors, such as the filter type, vacuum, and characteristics of the algae (for instance, cellular shape) in the sample. In the present study conducted in the Pearl River estuary, the dominant species were nano-chain-forming species, such as S. costatum, Ch. curvisetus, and Thalassiosira spp. (except for in summer). These species are normally in chains with lengths more than $20 \mu \mathrm{m}$ but comprised of many cells with sizes less than $20 \mu \mathrm{m}$. Therefore, they might pass through the $20 \mu \mathrm{m}$ filter when their chain lengths were less than 20 $\mu \mathrm{m}$ or when the cell colonies were oriented in such a way that their diameters were less than $20 \mu \mathrm{m}$. However, the pass rate of $S$. costatum through the $20 \mu \mathrm{m}$ mesh net was only $14.37 \%$ [76]. In summer, the dominant blue-green algae were colonial species with width or length larger than $20 \mu \mathrm{m}$, such as filamentous Trichodesmium spp., filamentous Pseudoanabaena sp., and rectangular M. tenuissima. Thus, micro-Chl $a$ concentration measurements included some of those cells as part of the nano-fraction. This may be another possible explanation why the dominant species was $S$. costatum in both spring and autumn, while the dominant size classes were different.

The authors would like to thank all of the investigators involved in this project, either in the collection of samples or the supporting data used, for their cooperation. Comments from three anonymous reviewers are gratefully acknowledged. Professor John Hodgkiss of The University of Hong Kong is thanked for his assistance with English. This work was supported by the National Basic Research Program of China (2010CB428702), Public Science and Technology Research Funds Projects of Ocean (201005015), National Science \& Technology Pillar Program of China (2012BAC07B05)
1 Cloern J E, Dufford R. Phytoplankton community ecology: Principles applied in San Francisco Bay. Mar Ecol Prog Ser, 2005, 285: 11-28

2 Butrón A, Iriarte A, Madariage I. Size-fractionated phytoplankton biomass, primary production and respiration in the Nervión-Ibaizabal estuary: A comparison with other nearshore coastal and estuarine ecosystems from the Bay of Biscay. Cont Shelf Res, 2009, 29: 10881102

3 Fu M Z, Wang Z L, Li Y, et al. Phytoplankton biomass size structure and its regulation in the Southern Yellow Sea (China): Seasonal variability. Cont Shelf Res, 2009, 29: 2178-2194

4 Malone T C. Algal size. In: Morris I, ed. The Physiological Ecology of Phytoplankton. London: Blackwell Scientific Publications, 1980. 433-465

5 Platt T, Silver W. Ecology, physiology, allometry and dimensionality. J Theor Biol, 1981, 93: 855-860

6 Tamigneaux E, Legendre L, Klein B, et al. Seasonal dynamics and potential fate of size-fractionated phytoplankton in a temperate nearshore environment (Western Gulf of St. Lawrence, Canada). Estuar Coast Shelf S, 1999, 48: 253-269

7 Raven J A. The twelfth Transley Lecture. Small is beautiful: The picophytoplankton. Funct Ecol, 1998, 12: 503-513

8 Finkel Z V, Irwin A J, Schofield O. Resource limitation alters the 3/4 size scaling of metabolic rates in phytoplankton. Mar Ecol Prog Ser, 2004, 273: 269-279

9 Cermeño P, Maraón E, Rodríguez J, et al. Large-sized phytoplanktion sustain higher carbon specific photosynthesis than smaller cells in a coastal eutrophic ecosystem. Mar Ecol Prog Ser, 2005, 297: 51-60

10 Cermeño P, Maraón E, Pérez V, et al. Phytoplankton size structure and primary production in a highly dynamic coastal ecosystem (Ría de Vigo, NW-Spain): Seasonal and short-time scale variability. Estuar Coast Shelf S, 2006, 67: 251-266

11 Marañón E, Cermeño P, Rodríguez J, et al. Scaling of phytoplankton photosynthesis and cell size in the ocean. Limnol Oceanogr, 2007, 52: $2190-2198$

12 Marañón E. Inter-specific scaling of phytoplankton production and cell size in the field. J Plankton Res, 2008, 30: 157-163

13 Zhao H T. Evolution of the Pearl River Estuary (in Chinese). Beijing: Ocean Press, 1990

14 Chen Y T, Luo Z R. Modern sedimentary velocity and their reflected sedimentary characteristics in the Pearl River Mouth (in Chinese). J Trop Oceanol, 1991, 10: 57-64

15 Huang X P, Huang L M, Yue W Z. The characteristics of nutrients and eutrophication in the Pearl River estuary, South China. Mar Pollut Bull, 2003, 47: 30-36

16 Tang Y L. The Analysis and Countermeasure of Environmental Problem in China (in Chinese). Guangzhou: Zhongshan University Press, 1997

17 Wen W Y, Zhang G X, Du W C. A study on water pollution in the Zhujiang (Pearl River) estuary. In: Wong C K, Chu K H, Chen Q C, et al, eds. Environmental Research in Pearl River and Coastal Area (in Chinese). Guangzhou: Guangdong Higher Education Press, 1995. 99-108

18 Yin K D, Qian P Y, Wu M C S, et al. Shift from P to N limitation of phytoplankton growth across the Pearl River estuarine plume during summer. Mar Ecol Prog Ser, 2001, 221: 17-28

19 Boudreau P R, Dickie L M, Kerr S R. Body-size spectra of production and biomass as system-level indicators of ecological dynamics. $\mathrm{J}$ Theor Biol, 1991, 152: 329-339

20 Sin Y, Wetzel R L, Anderson I C. Seasonal variations of size fractionated phytoplankton along the salinity gradient in the York River Estuary, Virginia. J Plankton Res, 2000, 22: 1945-1960

21 Cai Y M, Ning X L, Liu Z L. Studies on primary production and new production of the Zhujiang Estuary, China (in Chinese). Acta Oceanol Sin, 2002, 24: 101-111

22 Yin K D, Zhang J L, Qian P Y, et al. Effect of wind events on phytoplankton blooms in the Pearl River estuary during summer. Cont Shelf Res, 2004, 24: 1909-1923

23 Huang B Q, Hong H S, Ke L, et al. Size-fractionated phytoplankton 
biomass and productivity in the Zhujiang River Estuary in China. Acta Oceanol Sin, 2005, 27: 180-186

24 Qiu D J, Huang L M, Zhang J L, et al. Phytoplankton dynamics in and near the highly eutrophic Pearl River Estuary, South China Sea. Cont Shelf Res, 2010, 30: 177-186

25 Grasshoff K, Kremling K, Ehrhardt M. Methods of Seawater Analysis. Weinheim: Wiley-VCH, 1999. 600

26 Parsons T R, Maita Y, Lalli C M. A Manual of Chemical and Biological Methods for Seawater Analysis. New York: Pergamon Press, 1984. 22-25

27 Utermöhl H. Zur Vervollkommnung der quantitativen Phytoplankton-Methodik. Mitteilungen der. Internationale Vereinigung für theoretischeund angewandte Limnologie, 1958, 9: 1-38

28 Buchanan C, Lacouture R V, Marshall H G, et al. Phytoplankton reference communities for Chesapeake Bay and its Tidal Tributaries. Estuar, 2005, 28: 138-159

29 Lin I, Liu W T, Wu C C, et al. New evidence for enhanced ocean primary production triggered by tropical cyclone. Geophys Res Lett, 2003, 30: 1718

30 Chang J, Chung C C, Gong G C. Influences of cyclones on chlorophyll a concentration and Synechococcus abundance in a subtropical western Pacific coastal ecosystem. Mar Ecol Prog Ser, 1996, 140: 199-205

31 Delesalle B, Pichon M, Frankignoulle M, et al. Effects of a cyclone on coral reef phytoplankton biomass, primary production and composition (Moorea Island, French Polynesia). J Plankton Res, 1993, 15: 1413-1423

32 Kiørboe T. Turbulence, phytoplankton cell size and the structure of pelagic food webs. Adv Mar Biol, 1993, 29: 1-72

33 Agawin N R S, Duarte C M, Agustí S. Nutrient and temperature control of the contribution of picoplankton to phytoplankton biomass and production. Limnol Oceanogr, 2000, 45: 591-600

34 Dortch Q, Whitledge T E. Does nitrogen or silicon limit phytoplankton production in the Mississipi River plume and nearby regions? Cont Shelf Res, 1992 ,12: 1293-1309

35 Zhang J, Yu Z G, Wang J T, et al. The subtropical Zhujiang (Pearl River) estuary: Nutrient, trace species and their relationship to photosynthesis. Estuar Coast Shelf S, 1999, 49: 385-400

36 Harrison P J, Yin K D, Lee J H W, et al. Physical-biological coupling in the Pearl River Estuary. Cont Shelf Res, 2008, 28: 1405-1415

37 Yin K D, Qian P Y, Chen J C, et al. Dynamics of nutrients and phytoplankton biomass in the Pearl River estuary and adjacent waters of Hong Kong during summer: Preliminary evidence for phosphorus and silicon limitation. Mar Ecol Prog Ser, 2000, 194: 295-305

38 Murphy L S, Haugen E M. The distribution and abundance of phototrophic ultraplankton in the North Atlantic. Limnol Oceanogr, 1985, 30: $47-58$

39 Marañón E, Berhenfeld M J, González N, et al. High variability of primary production in oligotrophic waters of the Atlantic Ocean: Uncoupling from phytoplankton biomass and size structure. Mar Ecol Prog Ser, 2003, 257: 1-11

40 Riegman R, Kuipers B R, Noordeloos A A M, et al. Size-differential control of phytoplankton and the structure of plankton communities. Netherlands J Sea Res, 1993, 31: 255-265

41 Rodríguez J, Tintore J, Allen J T, et al. Mesoscale vertical motion and the size structure of phytoplankton in the ocean. Nature, 2001, 410: 360-363

42 Wong M H, Cheung K C. China Estuarine Systems: Pearl River Estuary and Mirs Bay. In: Smith, S V, Dupra V, Crossland M, et al, eds. Estuarine Systems of the South China Sea Region: Carbon, Nitrogen and Phosphorus. LOCIZ Reports and Studies No.14, LOICZ, Texel, The Netherlands, 2000. 7-16

43 Probyn T A. Nitrogen uptake by size-fractionated phytoplankton populations on the southern Benguela upwelling system. Mar Ecol Prog Ser, 1985, 22: 249-258

44 Sin Y, Wetzel R L, Anderson I C. Seasonal variations of size fractionated phytoplankton along the salinity gradient in the York River Estuary, Virginia. J Plankton Res, 2000, 22: 1945-1960
45 Banse K. Grazing, temporal changes of phytoplankton concentrations, and the microbial loop in the open sea. In: Falkowski P G, Woodhead A D, eds. Primary Productivity and Biogeochemical Cycles in the Sea. New York: Plenum Press, 1992. 409-440

46 Uye S. Impact of copepod grazing on the red-tide flagellate Chattonella antiqua. Marine Biol, $1986,92: 35-43$

47 Bautista B, Harris R P. Copepod gut contents, ingestion rates and grazing impact on phytoplankton in relation to size structure of zooplankton and phytoplankton during a spring bloom. Mar Ecol Prog Ser, 1992, 82: 41-50

48 Nejstgaard J C, Bamstedt U, Bageoien E, et al. Algal constraints on copepod grazing. Growth state, toxicity, cell size, and season as regulating factors. ICES J Mar Sci, 1995, 52: 347-357

49 Hansen B W, Hygum B H, Brozek M, et al. Food web interaction in a Calanus finmarchicus dominated pelagic ecosystem-A mesocosm study. J Plankton Res, 2000, 22: 569-588

50 Tan Y H, Huang L M, Chen Q C, et al. Seasonal variation in zooplankton composition and grazing impact on phytoplankton standing stock in the Pearl River Estuary, China. Cont Shelf Res, 2004, 24: 1949-1968

51 Li K Z, Yin J Q, Huang L M, et al. Spatial and temporal variations of mesozooplankton in the Pearl River estuary, China. Estuar Coast Shelf S, 2006, 67: 543-552

52 Li K Z, Yin J Q, Huang L M, et al. Study on planktonic copepods ecology in the Pearl River estuary (in Chinese). Ecol Sci, 2007, 26: 97-102

53 Fang H D, Zhu A J, Dong Y H, et al. Study on the variations of zooplankton community in the Pearl River Estuary in 2005-2006 (in Chinese). Taiwan Strait, 2009, 28: 30-37

54 Wong L Y, Chen J X, Xie H, et al. A model study of the circulation in the Pearl River Estuary (PRE) and its adjacent coastal waters: 1. Simulations and comparison with observations. J Geophys Res, 2003, 25: $1-17$

55 Dong Y H, Cai J D, Qian H L. Nutrient Ratios and its Relationship with Phytoplankton in the Pearl River Estuary (in Chinese). Mar Sci Bull, 2009, 18: 3-10

56 Dai M, Li C H, Jia X P, et al. Ecological characteristics of phytoplankton in coastal area of Pearl River estuary (in Chinese). Chin J Appl Ecol, 2004, 15: 1389-1394

57 Tilman D. Resource competition between planktonic algae: An experimental and theoretical approach. Ecology, 1977, 58: 338-348

58 Lewin J C. Silicification. In: Lewin R A, ed. Physiology and Biochemistry of Algae. New York: Academic, 1962. 445-455

59 Egge J K. Are diatoms poor competitors at low phosphate concentrations? J Marine Syst, 1998, 16: 191-198

60 Zhou M J, Shen Z L, Yu R C. Responses of a coastal phytoplankton community to increased nutrient input from the Changiiang (Yangtze) River. Cont Shelf Res, 2008, 28: 1483-1489

61 Li R X, Zhu M Y, Wang Z L, et al. Mesocosm experiment on competition between two HAB species in East China Sea (in Chinese). Chin J Appl Ecol, 2003, 14: 1049-1054

62 Huang L M, Jian W J, Song X Y, et al. Species diversity and distribution for phytoplankton of the Pearl River estuary during rainy and dry seasons. Mar Pollut Bull, 2004, 49: 588-596

63 Elliott J A. Is the future blue-green? A review of the current model predictions of how climate change could affect pelagic freshwater cyanobacteria. Water Res, 2012, 46: 1364-1371

64 Elliott J A. The seasonal sensitivity of Cyanobacteria and other phytoplankton to changes in flushing rate and water temperature. Global Change Biol, 2010, 16: 864-876

65 Wen W Y, Huang X P, Zhang G X. Discussion on water pollution across multi-regional in the Pearl River estuary. In: Lin J Z, Zhu T, $\mathrm{Hu}$ E B, eds. Proceedings of the China Mainland-Hong Kong Symposium on Regional Environmental Impact Assessment (in Chinese). Hong Kong: Open University of Hong Kong Press, 1999. 471478

66 Wong G T F, Gong G C, Liu K K, et al. 'Excess nitrate' in the East China Sea. Estuar Coast Shelf S, 1998, 46: 411-418 
67 Zhang J, Yu Z G, Raabe T, et al. Dynamics of inorganic nutrient species in the Bohai seawaters. J Marine Syst, 2004, 44: 189-212

68 Jickells T D. Nutrient biogeochemistry of the coastal zone. Science, 1998, 281: 217-222

69 Smayda T J. Novel and nuisance phytoplankton blooms in the sea: Evidence for a global epidemic. In: Granéli E, Sundström B, Edler B, et al, eds, Toxic Marine Phytoplankton. New York: Elsevier, 1990. $29-40$

70 Humborg C V, Ittekkot E, Cociasu A, et al. Effect of Danube River dam on Black Sea biogeochemistry and ecosystem structure. Nature, 1997, 386: 385-388

71 Wei H, Sun J, Moll A, et al. Phytoplankton dynamics in the Bohai Sea-observations and modeling. J Marine Syst, 2004, 44: 233-251

72 Khan S, Haque M M, Arakawa O, et al. Physiological observations on a diatom Skeletonema costatum (Greville) Cleve. Bangladesh J Fisheries Res, 1998, 2: 109-118

73 Munawar M, Munawar I F, Leppard G G. Early warning assays: An overview of toxicity testing with phytoplankton in the North American Great Lakes. Hydrobiologia, 1989, 188/189: 237-246

74 Snoeijs P, Busse S, Potapova M. The importance of diatom cell size in community analysis. J Phycol, 2002, 38: 265-272

75 Nayar S, Goh B P L, Chou L M. Dynamics in the size structure of Skeletonema costatum (Greville) Cleve under conditions of reduced photosynthetically available radiation in a dredged tropical estuary. J Exp Mar Biol Ecol, 2005, 318: 163-182

76 Sun J, Liu D Y, Zhong H, et al. A Comparison of Three Methods for Studying Phytoplankton Size Fraction (in Chinese). J Ocean Univ Qingdao, 2003, 33: 917-924

Open Access This article is distributed under the terms of the Creative Commons Attribution License which permits any use, distribution, and reproduction in any medium, provided the original author(s) and source are credited. 